\title{
II 「個性の教育を考える」(公開シンポジウム)
}

司 会 者 梶田 飸一 (大阪 大学)

話題提供者 吉田 章宏 (東 京大 学)

伊藤 隆二 (横浜市立大学)

畠瀬稔 (京都女子大学)

指定討論者 吉崎 静夫（鳴門教育大学）

\section{企画の趣旨}

\section{暒田}

「個性」の問題は，教育を考える場合，あるいは個々人 の成長・発達を考える場合, 基本的な意味を持つ。しか し,この「個性」という概念自体が必ずしも明確でない。 単なる個人特性を問題とするもの, 個人差を問題とする ものから, 個々の独自性, ユニークさを問題にするもの, 主体性・実存性を問題とするものまで様々である。した がって,「個性の教育」と言う場合も,

1)一人ひとりにテストや調查を実施した上で，そのデー

夕に基づいて指導する。

2) 指導や規制を排除し，自分の心の赴くまま自由に活動 する場を設定する。

3)他の人と違うことを発言し，自分だけのやり方で行動 するようエ夫することを奖励する。

4) 自分自身の内面を掘り下げる場を設定し, 自分の内的 土台（実感・納得・本音）に基づいて発言, 行動でき るよう奖励する。

など，多様な発想となる。

われわれは，「見かけ」の個性，「見せかけ」の個性て なく，その人自身の内実としての個性，その人の生きる 原理としての個性を大事にしたい。そして，個性教育と いうことで，「その人がその人になりきっていく」過程を 援助する営みを考えたい。

そうした発想に立つと, 私自身の考え方では, 個性教 育は必然的に「内面性の教育」にならざるをえない。

いずれにせよ,このシンポジウムにおいては, 教育心 理学的な観点から「個性教育」についての概念的な混乱 を整理し, 理論的, 実践的な前進のための手掛かりを提 供したいと願うものである。

「個性の教育」とは何か？

\section{吉田 章宏}

「個性の教育」を考えるに当たっては, 適切な問いを問
うことが極めて大切である。「個性の教育』とは何か？」 と問わずに「個性の教育」を論ずることはできない。哲 学から独立して以来,「・・とは何か？」という問い は, 心理学にとって最も不得手な問いとなった。しかし, この問いを敢えて問う。

「個性」は抽象的で曖昧な概念である。辞書的定義では 役立たない。まず, 抽象概念の「個性」と「この人の個 性」における「個性」とを区別する必要がある。この事 情の理解には, 概念形成研究が助けになろう。フッサー ルの『現象学的心理学』に「色」概念の釈明がある。「こ のもの」,「このものの色」(赤, 黄, 青・・) と「色」の 関係は，「この人」，「この人の個性」(・・) と「個性」 の関係と,構造的に同型である。先天盲者にとっての「色」 概念は, 想像するに, 抽象的で曖昧, 無内容であろう。 色彩画家の「色」概念は具体的で微妙な多くの色彩で満 たされていよう。前者と後者では，その「色」概念の内 容は極めて異なる。「個性」概念にも同様の事情がある。 ここで，他者の個性を豊かにとらえるには，自らの個性 が豊かでなくてはならない，という困った事情が現れる。 さらに,「彼の心理学」,「汝の心理学」, および,「我の心 理学」の「三つの心理学」問題が加わる。現代の主流心 理学は,「彼の心理学」であり, 個性を個人差と同一視す る傾向と限界をもつ。人間を豊かにとらえねば，「個性」 概念も貣しくならざるを得ない。「個性」は「すべての人」 にあるとする立場と「個性的な人」にのみあるとする立 場の両者も視野に入れねばならぬ。文学は, 個性を豊か にとらえている。「本人にとっての実存的に重要な問 題」,「何を拒否するか」,「何を信じて行うか」がその個 性を定める，とするその思想に学びたい。心理学者／教 育者が豊かにならなければ個性の理解も貧しくなる。歴 史的に規定された自らの立場を越えて，もろもろの他者 の立場，更には，普遍的な立場をとることが出来る時， 人は真に個性的となる。

では，「個性の教育」とは何か，その解釈は「個性」, 「の」，「教育」それぞれの多義性により多義的となる。幾 つかの例を挙げよう。第 1 に，個人差に対応する教育が ある。初めに個人差があり，個人差を少なくするのを目 指すのが「個性の教育」だと言う。第 2 に, 個人差それ ぞれに応じた教育。たとえば, 能力別, 学力別, 進度別 の教育により，個人差に適切な目標の達成で安んじるの 
がそれだと言う。第 3 に, 多様な個性に発して, 教育に より, 同一化，一様化である社会化に向かうのがそれだ と言う。そして, 第 4 に, 同じく, 多様な個性に発して も，さらに豊かで多様な個性化に向かう，多様化を目指 す教育がそれだと言う。社会化と個人化の間, 一様化と 多様化の間を，教育は摇れ動いて来た。

では,「真の個性教育」とは何か。その理解そのもの が, それを理解する者の個性の表現であろう。私は, 個 人としては, 第 4 の立場を採りたい。その原理は,「多様 性を通じての統一性」(Unity through Diversity),「多 視点性」(Multi-perspectivity), そして,「事柄への忠実 性」(Fidelity to Phenomena) である。そうした教育 のためには, 教師自らが豊かで個性的であることが求め られる。教師とは「子どもと共に自らも豊かに育つこと を仕事とする人」であるからだ。

「個性の教育」を研究する研究者にもまた, 真に個性的 であることを通しての深く豊かな人間理解が求められて いる。多様な素材から均質で上質の製品を生産する, 品 質管理の行き届いた高能率の工場のイメージではなくて， 福岡正信氏の『自然農法』による, 多様な草木が互いに 助け合ってそれぞれが生かされて生きている農園のイ メージ，これが私個人の「個性の教育」のイメージであ る。

\section{個性の教育は同行（とうぎょう）の教育で}

\section{伊藤 隆二}

ほとんど本能によって生きている生物は「自分を自然 に合わせて」生きていくのに対し，本能のままでは生き ていけない生物である人間は「自分に自然を合わせて」 生きていくことに成功した。それは「教育」による。

ところで「教育」には万人に共通の普遍教育 (general education) と一人ひとりの個性教育（individuality education)という二面性がある。前者は主として社会適 応をもたらすのであるが，その中心をなすのは「能力」 と「協調性」であるため, 普遍教育は人間の「社会」に とっての有用性ないしは効用性の度合によってその価值 がはかられる。

しかし，今，社会適応というときの「社会」が何を目 指しているかが問われている。社会を形成しようとした 人間は，はじめから「産業をおこし，商業をすすめ，よ り多くの富を得，くらしを豊かにする，便利にする，快 適にする——ういう方向へすすめばすすむほど人びと は幸せになれる」といったパラダイムを描いていたよう である。現在でも，人びとのいとなみのすべてはこのパ ラダイムの実現にどの程度, 貢献しているかで評価され ている。いえ, 人間そのものがその貢献度で評価されて
いる,といってもよい。

ところで, 今地球規模での大污染（地球破壊）が問題 になっているが, そのみなもとには上のパラダイムが あったのではなかろうか。「経済発展」そのものが污染源 になっていること, そして, 大量生産, 大量消費の社会 の中で人間性 (human nature) そのものが侵されてい ること,つまりは人間性の重要な柱である，エゴを超え た人類愛・平和創造といった目的意識を支えている「魂」 (Seele)までが污染されていることに，気づかねばなら ない。

今, 個性教育が大切だといわれるのは, 人間の個々人 の人権 (wholesome and cultured lifeをいとなむ基 本的権利）が著しく侵されていることによる。

個性教育の前提は一人ひとりは独自であることそれ ゆえに一人ひとりは超絶していること, いいかえると一 人ひとりがそのままで尊いこと，他と比較も代替もでき ないこと，まとめていうと「尊厳性」は絶対であることを 認めることである。

教師（親）はみずから個性教育者であり，生徒のみず からの個性教育の実践を尊重し，同行（どうぎょう）す る—これが個性教育の真髄である。同行とは同じ心で 道を求めることであり, 求道といいかえてもよい。

普遍教育では「人間の普遍性」が尊ばれ，人間を能率 よく(効率よく), 社会適応へ導くことが眼目とされてい るため, 科学・技術に依拠する。そこでは「同一」(反 復, 複製, 同結果) と「合理性」が最高の価値となる。 教育科学, 教育技術は, 「法則」を求め, その「法則」ど おりに行えば，だれがやっても「同一」と「合理性」が 得られることを究極の目標としている。

個性教育は一人ひとりの「その人らしさ」(分割できな い全体としてはじめてその意味をもつ独自性）が花を咲 くことを願っているので,「人間の普遍性」を尊ぶ普遍教 育を支える「同一」と「合理性」はなじまない。個性教 育は芸術に通じる。

芸術では「同一」と「合理性」は否定される。芸術は 「法則」を必要としない。芸術は自由の中での創造性に よってもたらされる。芸術は感動（内面の世界からの叫 び)であり, 美であり, 精神であり, 宗教である。

つきつめていけば個性教育は宗教教育と大きく重なり, 深くつながっていく。

産業をおこし, 商業をすすめ, より多くの富を得, く らしを豊かにする—そのことで人びとは幸せになれる というパラダイムでは将来において人間はいっそう負し くなり，遂には自滅する一そう見通していた人は過去 にもいた。たとえばコンコード派（R.W.Emersonや Henry, D. Thorean)の人びとは，そうした見かけのうえ 
の豊かさではなく，人間の深い生き方一一れは神と自 然と人間の究極的合一を求め, 質素な, しかしゆずり合 いと補い合いと扶け合いという人間の基本的あり方を根 ずかせ, 瞋想を中心に自己の内面を探求する生き方に徹 した。その中心思想は「超絶主義（transcendentalism）」 である。

個性教育は一人ひとりは神の招命（calling）をうけて この世に誕生したことを自覚し, 一人ひとりの役割 (roll) をその人の歩み (pace) で全うすることを支える いとなみといえる。

宗教なき教育は知恵（能力）はすぐれているが悪をく りかえす悪魔をつくるいとなみでありつづけるだろう。

\section{個性の教育を阻む条件への気づきの必要}

\section{皇瀬稔}

I .「エンカウンター・グループ経験と人間中心の教育研 修会」のこと

わたしは過去40年近くC.R.Rogers の提唱した学習者 中心事業に関心をもってきた。また,この20数年間, エ ンカウンター・グループ（以下 EG と略す）の研究に携 わってきた。この両者が教師の心理的成長に極めて効果 的であることを見てきたので，1979年以来，両者をドッ キングさせ,「エンカウンター・グループ経験と人間中心 の教育研修会」と称するワークショップとセミナーを毎 年開催してきている。

それは, (1)10人前後の小 EG 経験による自己への気づ きと他者への深い理解の促進, (2)大グループ（多くは 1 会場 40 ～ 60 人の全体会) における one way communication に宿らないでの多様な個性的意見の交流と意志 決定を進めるコミュニティづくりの体験学習, (3)古賀一 公らの開発した「ひとり学習」により, 一斉学習を最小 にして, ひとりひとりが自己の課題に直面し, 教師はそ れを援助する学習相談に大半を費すなどの「人間中心の 学習法」の開発と交流から成っている。

\section{II . 教師たちの個性的実践が日本の社会で阻まれる現実}

この研修会を経験した多くの教師が，その生徒たちを 自己実現的に援助しようとする多くの試みがなされてい ることが認められる。(畠瀬, 1990)しかし, これらの教 師をとりまく現実は, しばしばその試行を阻む形で存在 しているのである。

例えば，新しい実践を「厄介物」視し，ふつうの一斉 授業へもどすよう忠告する校長, 参観者が相次いだため に左遷されたとしか考えられない教委の人事, 同一歩調 をとることを強調してその学級単独での保護者との話し 合い会合に明らさまに反対を示す主任や同僚。EG 経験
をもった教師にとっては，親との集いを開いて子供の問 題を共に考えたいという願いは自然の歩みであるが, こ のような意欲的な試みが陰に陽に阻まれるのを見てきた。 現在, 明らさまに新しい試行を進めている教師たちは, 周囲が一目おかざるをえない大物教師か, よほどの信念 の持主でないと不可能に近い現実がある。

III. 学校という組織による“没個性化”の拡大再生産

既に大会発表論文集 (S.16) に述べたが，上述のような 新しい試行を阻む風土は, 日本文化に内在する歴史的, 社会的, 文化的特徴の端的な表われであろう。加えて, 教職に固有な防衛的態度（落ち度のない行動を意図する ために過度に形式的で, 真実の対話を避ける傾向)によっ て, 細々とした校則をつくり, 上から下への権力行使と いう形での強制をするなど, 個性を尊重することとはか け離れた実態が存在していることを, 我々は直視しなけ ればならない。

IV. 教育組織と教員養成のあり方の抜本的改善への提案 当面，次の 3 点を提起したい。

(1) 文部省 $\rightarrow$ 教委 $\rightarrow$ 校長 $\rightarrow$ 主任という“権力的”に上 $\rightarrow$ 下へとおりてゆく構造が, 著しく個性の発達を阻害して いることについて認識する必要がある。

（2）個々の教師もまた生徒や保護者に対しては“権力 者”であることを認識する必要がある。

(3) 現行の教員養成は, 知識・技能の習得を中心にす る傾向があるが, 自己への気づき, 他人への共感的理解, 対話のできる教師になることが, 個性を育てる風土作り の必須前提であり，そのためには対人能力についての学 習が“体験的”になされる必要がある。

\section{引用文献}

畠瀬稔 1990 エンカウンター・グループと心理的成長 創元社（特に第 8 章, 第 9 章）

\section{指定討論者の立場}

吉崎 静夫

指定討論者の立場から, 次のような討論の観点を提案 した。

（1）学校教育の目標としての「個性」とは何を意味し ているのだろうか。つまり，どのような生徒を育成する ことが「個性の教育」の目標なのだろうか。

ところで, 司会者と話題提供者は次のように個性をと らえていた。

梶田氏は，「自分の内面世界に原理的なものが育つこ と。そして, 自分なりの生き方ができるようになること」 
と考えている。そこには, 自分自身の実感・本音・納得 の世界を大切にしてほしいという氏のねがいがある。

吉田氏は，「個性は在ったり無かったりするのか, ある いは，ただ，見えたり見えなかったりするだけなのか」 といった議論を展開した後に, 個性と個人差とを区別し ている。つまり, 前者は多様化が前提となっているのに 対して, 後者は一様化が基本となっているという。

伊藤氏は，「その人らしさを表わすものであって, 独自 性や個別性という特徴をもつ」ととらえている。そして, 「人間としての普遍性」を意味する常識とは対比されると いう。

畠瀬氏は，「自己実現的でユニークなものであって，多 様な価值観にささえられている」と考えている。

これらの個性のとらえ方は, 学校教育の目標としての 個性を考える手がかりを私たちに与えてくれる。

例えば，判断・行動の原理や価値観といった内面世界 の中にみられる個性と自己実現や興味・関心といった外 面にみられる個性との関係をどのようにとらえたらよい のかということである。つまり, 個性のあらわれをウチ とソトからどのように考えたらよいのかということであ る。このことは,「個性の教育」の目標を考えるさいに特 に重要な視点となる。教育心理学の知見や概念はこの点 にどのような貢献をしているのだろうか。

（2）学校教育に課せられた主な使命の 1 つに「基礎学 力の充実 (つまり, 学力保障)」ということがあるが, こ のことと「個性の伸長 (成長保障)」とは学校カリキュラ ムの中でどのようなバランスを保たねばならないのか。
つまり，「共通性（社会性）」と「個性（個別性）」とのバラ ンスを学校教育の中でどのように考えればよいのか。

伊藤氏によれば,「人間としての普遍性」は社会適応と しての常識を意味し,「人間としての個別性」は社会変革 として反常識を意味している。そして, 個性の教育は身 につけた常識を破壊するところにその特徴があるという ことである。また，梶田氏によれば，社会化は「社会の メンバーになること」を意味し，個性化は「その人がそ の人になること」を意味している。

わが国の教育の特徵を考えた場合, 共通性を育てる教 育よりも個性を育てる教育がより強調される必要がある。 というのは, 畠瀬氏の指摘のように, 「調和を重んじ, 突 出を嫌い, 集団のまとまりを強調するわが国の文化や社 会は, 個性的生き方を著しく困難にする」からである。 しかしながら，共通性の教育があまりにも脆弱になると， たんに自己主張の強い生徒や変わり者の生徒を育てるこ とにもなりかねない。両者のバランスは, まさにわが国 の教育界における今日的課題である。

（3） 21 世紀の社会に活躍するためには, 生徒は個性と 国際性を共に身につけなければならないと思うが, 学校 教育ではこれらをどのように関連させて考えていたらよ いのか。

ここでは,「文化の違いの理解, つまり, 異質の価值観 の許容（畠瀬氏）」と「他の人にとっての真実にも虚心に 耳を傾け, 自他の見解を練りあげること(梶田氏)」といっ た指摘を学校教育の中で考えてみる必要があるように思 われる。

\section{III＼cjkstart教職課程としての教育心理学はどうあるべきか}

司会 者 中西 信男 (大 阪大学) 話題提供者 細谷 純 (東 北大 学) 内藤 勇次 (兵庫教育大学) 原野広太郎 (筑 波 大 学) 指定討論者 武衛 孝雄 (大手前女子大学)

\section{主旨}

中西 信男

昭和 24 年以来, 40 年ぶりに教育職員免許法の改正があ り, 教職に関する専門科目の大幅な改訂が行われ, これ まで「教育原理」および「教育心理学」各 4 単位と定め られた専門科目が今回は「教育の本質及び目標に関する 科目」,「幼児, 児童又は生徒の心身及び学習の過程に関
する科目」,「教育に係る社会的, 制度的又は経営的な事 項に関する科目」,「教育の方法及び技術（情報機器及び 教材の活用を含む) に関する科目」, 各 2 単位になった。 さらに従来からある「教科教育法に関する科目」( 3 単 位),「道徳教育に関する科目」( 2 単位), 「教育実習」( 3 単位)に加えて, 「生徒指導, 教育相談及び進路指導に関 する科目」( 2 単位), 「特別活動に関する科目」( 1 単位) が追加された。

従来の「教育心理学」( 4 単位) は, 今回の改訂では「幼 児, 児童又は生徒の心身の発達及び学習の過程に関する 科目」( 2 単位) と「生徒指導, 教育相談及び進路指導に 関する科目」( 2 単位), それに関連する「特別活動に関 する科目」( 1 単位) や「教育の方法及び技術（情報機器 